\title{
ELS TOPÒNIMS ARAB̀IGO-CATALANS DEL BAIX SEGURA (ALACANT)
}

\author{
MARIAA JESÚS RUBIERA MATA
}

Malgrat el seu actual monolingüisme castellà, la primera llengua romànica que es va parlar al Baix Segura va ser, sense dubte, el català i la desaparició d'aquest és deguda a la progressiva immigració murciana en època moderna. La raó d'aquella primacia va ser la presència de repobladors catalans fins $i$ tot abans de la revolta mudèjar de 1264, presència esdevinguda majoritària a partir de $1266 \mathrm{com}$ va provar M. T. Ferrer i Mallol (1). La prova de la presència de la llengua catalana es troba en els topònims $d^{\prime}$ origen àrab que ofereixen les formes dels arabismes del calatà, que no presenten els arabismes del castellà, i que no són degudes a les varietats dialectals de l'àrab hispànic com suposen alguns autors (2), sinó a la llengua receptora, cartellà o català, que reprodueix els fonemes àrabs segon la seua especifica fonologia.

Alguns d'aquests fenòmens diferenciadors entre els arabismes del català i del castellà sóns: la IW/ o bilabial semiconsonant dóna en castellà la vocal /u/ i en català la /v/ o labiodental fricativa sonora: Fawwara (Font abundosa): Alfaguara (cast.) i Favara (cat.); la $/ \mathrm{n} /$ dental nasal final darrere vocal accentuada es perd en català. En canvi en castellà i portugués es conserva i fins i tot en alguns casos apareix una nasal epentètica Rumman: Abenromà (cat.) Guadaromán (cast.); al-bardi: bardín (cast.) (3). Les tres aspirades àrabs /kh/, $/ \mathrm{h} / \mathrm{i} / \mathrm{h} /$ (uvular, faringal i glota) emmudeixen en xastellà mentre que en català es transformen en /f/: al-Buhayra (llacuna): Albuera (cast.) i Albufera (cat.).

(1) M. T. FERRER i MALLOL: "Toponimia Medieval d'Oriola" Miscel.lania d'homenatge a Enric Moreu-Rey Volum II. Barcelona, 1988, pp. 195-211.

(2) Antoni M. BADIA i MARGARIT: Gramàtica històrica catalana, València, 1981. Un ca més greu perquè és la tesí d’una memòria doctoral es pot veure en la meua nota "Precisiones sobre los dialectos arábigogranadino y arábigo-valenciano" Sharq al-Andalus 1 11984), pp. 181-162.

(3) F. CORRIENTE: A grammatical skatch of the spanish arabic dialect bundle, Madrid, 1977 p. 41 nota 46. 
Aquests tres fenòmens es donen en els topònims àrabs del Baix Segura a favor del català com a testimoni de la presència del català i de la seua perduració durant segles. Donarem tres exemples significatius per ser a més llocs que pertanyen a l'anomenada toponmia major: Rafal, Redovà i Almoradí.

RAFAL. Ja hem estudiat aquest topònim en altre lloc (4). El seu ètim és la paraula aràbigo-hispànica Rahal amb el significat de "pleta per al ramat» segon el Vocabulista in Arabico. De vegades els rafals eren també escorxadors i llocs on es venia la carn del ramat i per aixó l'arabisme cafalí «carn malaltissa" (5).

L'arabisme castellà és Raal, topònim que es troba prop del Rafal del Baix Segura, ja en la provincia de Múrcia.

REDOVÀ. L'ètim d'aquest topònim és l'antropònim àrab Ridwan. Segons el Repartiment d'Oriola (6) el nom àrab sencer d'aquest lloc era Beni-Ridwan i apareix amb la forma casteliàna Beniriduan i Benerredoan i la catalana Beniredovà. Ja hem dit adés que la $/ w /$ dóna uen castellà i ve en català, a més de la pèrdua de la ena final derrere vocal accentuada en aquesta llengua. Els dos fenòmens es donen en aquest topònim: Riduan en castellà i Redovà en català. Va prevaler la forma catalana per la presència majoritària medieval d'aquesta llengua. La forma actual de Redován és un castellanisme modern com la e final de Crevillent.

ALMORADí. L'etimologia d'aquest topònim es va descobrir pel text del geògraf andalusí al-Udri que parla d'un lloc anomenat Al-Muwalladin - «els conversos a I'Islam» - prop de la sesmbocadura del riu Segura. L'evolució del nom és molt clara, però en castellà seria Almoradín per la tendència d'aquesta llengua a conservar la nasal àrab final $i$, fins $i$ tot, afegir-la darrere vocal accentuada. La forma Almoradí és un arabisme català claríssim.

(4) M. J. RUBIERA MATA: "Rafals y reales; ravals y rebales; reals y reales" Sharq al-Andalus 1 (1984) pp. 117-122.

(5) Màrius BEVIÁ: «Bovalars, carns i rafals: la casa del rafalí d'Alacant" Sharq al-Andalus 2 (1985) pp. 115-117.

(6) FERRER i MALLOL: op. cit. supra p. 201. 